\title{
READING ACQUISITION AMONG 5- TO 6-YEAR-OLD CHILDREN IN THE PROGRAMME OF COMPULSORY PREPARATION FOR SCHOOL
}

\author{
Sandra Zariņa \\ Daugavpils University, Latvia
}

\begin{abstract}
In the context of compulsory education for 5-6 year-old children, the question about reading acquisition is one of fundamental concerns for both pre-school teachers and parents. This article examines the methods of reading acquisition frequently applied in preschool, discusses the situation and teachers'view of reading acquisition in pre-school in Latvia and provides suggestions for reading literacy development of 5-6 years old children based on the keystones of sustainable development. The article is a contribution in the construction of a theoretically grounded and sustainable model of reading acquisition for 5-6 year-old children meeting global educational challenges and Latvian local needs.
\end{abstract}

Key words: pre-school, reading literacy, reading acquisition, holistic approach, phonics method, sustainability.

\section{Introduction}

Contemporary society faces an incessant increase in the amount of information. This situation encourages many scholars across the world to seek new opportunities for improving the quality of reading acquisition. Considerable attention is thus focused on researching the opportunities for reading acquisition among preschoolers (Chan, Juana, \& Foon, 2008; Justice, Kaderavek, Fan, Sofka, \& Hunt, 2009; Hay \& Fielding-Barnsley, 2007; Roberts, Jurgens, \& Burchinal, 2005; Horner, 2004; Molfese, 2006). The studies that have been performed thus far indicate that the age from 2 to 6 is the most conductive to reading acquisition and share international experience in the organisation of reading acquisition processes. This article examines the experience of Latvia at the beginning of the $21^{\text {st }}$ century in promoting reading literacy of 5- to 6-year-olds. The study also contains a critical evaluation of the existing situation in the area of reading acquisition, which can be used for organising a purposeful and long-term development oriented reading acquisition process among preschoolers.

Since 1 September 2002, the preparation of 5- to 6-year-old children for the acquisition of basic education is compulsory in Latvia (Izglītības likums 2001. gada 5. jūlija likuma redakcijā). As yet, however, the content to be acquired in preparatory groups for 5to 6-year-old children is not clearly determined and no methodical suggestions are provided for teachers and parents. Thus each teacher thinks and works as he or she sees fit. Consequently, upon entering school first year pupils' skills differ considerably, which already for many years has provoked dissatisfaction among parents and teachers alike (Anspoka, 2009; Obligātās pirmsskolas un sākumskolas izglīî̉bas izvērtējums un pilnveides iespējas, 2009). Lack of a unified content is particularly acute for reading acquisition in groups of 5- to 6-year-olds. Anspoka (2009) admits that Latvia lacks extensive theoretical 
and empirical research about reading acquisition opportunities in pre-school and that seeking sustainable solutions for solving the problems of reading acquisition has been unnecessarily delayed. Teachers and parents have no clear answer as to when and how a child should be taught to read, how much he or she should be able to accomplish upon entering school - know the letters in his or her name or even all letters, be able to read by joining sounds into syllables or read fluently. Experience of specialists in pedagogy (Доман \& Доман, 2008; Амонашвили, 1996; Chan, Juana, \& Foon, 2008) and psychology (Vigotskis, 2002; Puškarevs, 2001; Svence, 1999; Chak, 2007; Horner, 2004) around the world proves that ever since a child is born he or she displays the need to cognise the world.

The present article describes the initial stage of a systematic research that could be used for the systematisation of the content and process of reading acquisition in Latvian pre-school education institutions. In this article, reading literacy is viewed in the context of sustainable development both by analysing the current situation in Latvia and by proposing suggestions for sustainability-oriented development of reading literacy in pre-school education institutions. Such focus was chosen because it is essential to consider not only how to teach a child to read, but also how to help retain interest in reading by creating a positive reading experience and ensure the development of active reader's position at a time when the modern technologies suggest plenty of alternatives for information acquisition and leisure.

The necessity to view reading literacy in the context of sustainable development is confirmed by research on the Progress in International Reading Literacy Study 2006 conducted by the International Association for the Evaluation of Education Achievement, which reveals that in 2006 reading literacy achievements of primary school pupils in Latvia have decreased compared to year 2001 (Geske \& Ozola, 2007). It means that a time when the world discusses reading as a significant life skill (Nurmilaakso, 2009; Prets, 2000), practical experience that has been accumulated by Latvian pre-school teachers during several years of independently teaching reading fails to provide the desired longterm results.

The article is structured inductively, that is, it begins with empirical situation analysis regarding development of reading literacy of 5- to 6-year-old children in compulsory pre-school education groups in Latvia. By examining the opportunities of reorienting reading acquisition in pre-school towards sustainable development, four methods for reading acquisition in the context of sustainable development are analysed. Discussion section contains suggestions that were devised on the grounds of the strong points of the above-mentioned methods and are aimed at promoting sustainable reading acquisition.

\section{Situation analysis}

This section of the article examines the period of seven years (from 2002 until 2009) beginning from the introduction of compulsory preparation for acquisition of basic education in Latvia, in order to review the situation regarding reading acquisition in preschool education institutions. 
Content analysis and evaluation of normative documents and methodical suggestions published in 2002-2009 regarding reading acquisition of 5- to 6-year-old children during their preparation for school.

During this research stage analysis of educational documents was used as data collection method. It helps to review the planned educational content stipulated in standards, guidelines, curricula, educational documents (Geske \& Grīnfelds, 2006). In this article normative, documents and methodical suggestions were analysed qualitatively described verbally (Geske \& Grīnfelds, 2001).

The handbook "Es gribu iet skolā [I Want to Go to School]" (Kaņepēja, 2003a) can be considered as one of the first attempts to supply pre-school teachers with methodical support for working in compulsory preparatory groups. The authors of this book opine that reading acquisition is related to a simplified approach to preparation for school. Although the significance of 'indirect reading acquisition' during play lessons is identified (Kañepēja, 2003b), its interpretation is ambiguous. Kaņepēja (2003b) writes the following about reading acquisition: "When preparing for school, the child ought to be competent in letters and interested in learning them". This statement is contradictory: on the one hand, knowing letters is required while, on the other hand, it is stated that mere interest in letters is sufficient. When answering the question: "Should the child know how to read?" Kanepejja argues that "at the final phase of preparation for school children ought to read with comprehension. It means that the child understands what he or she is reading and is able to tell what he or she has read about" (Kanepēja, 2003b, p. 12). Thus reading literacy in preschool is perceived as interest in letters, recognising letters, as well as reading and making sense of the text that has been read. It means that pre-school teachers' responsibility for children's reading acquisition is not specified and we can observe a lack of successiveness between pre-school education and the $1^{\text {st }}$ form.

Another recommendation document related to preparation of 5- to 6-year-olds for acquisition of basic education is entitled "Pamatprasmes pirmsskolēnam, uzsākot pamatizglītības apguvi [Preschooler's Basic Skills upon Commencing Acquisition of Basic Education]", published in 2005 by Latvian Education Content and Examination Centre. This document ought clearly to outline the reading literacy that the child should display upon entering school.

Yet these basic skills also fail clearly to answer the aforementioned question. Reading with comprehension and even the child merely taking up a book or asking about an unknown letter are all considered the beginnings of reading acquisition. It can be deemed positive that the aforementioned requirements respect differences in children's individual development by admitting that the moment when interest in reading and the need to read arise can vary from child to child. These requirements, however, do not demand a preschool teacher to assume responsibility for reading acquisition of children while the course books and workbooks for $1^{\text {st }}$ form are designed in such a way as to only be applicable with children who enter school already knowing how to read (Anspoka, 2009). Anspoka (2009) argues that in this case primary school teachers emphasise poor effectiveness of preparation for school of 5- to 6-year-olds whereas pre-school teachers believe that schoolteachers' demands regarding first formers' reading literacy are exaggerated.

While the lack of successiveness in pre-school and primary school educational content (Anspoka, 2009) is being debated at pedagogical level and while it is still unclear who should be the one to teach the child how to read - pre-school or primary school teacher, the majority of work remains to be done by parents (teach children how to read) and children themselves (learn to read as soon as possible) (Светловская \& Пиче-Оол, 
2007). Consequently, the child learns how to read because the teacher and parents demand it and not because he or she is interested and wishes to do so. Such learning is in conflict with constructivism, on which sustainable learning process is grounded (Ojala \& Talts, 2007; Stephen, 2003; Watkins, Ruth, Bunce, \& Betty, 1996), and the child risks developing an early notion of reading as a dull, tedious and tiresome process (Anspoka, 2009). It means that children who have mastered reading as a purely technical skill, following the demands set by adults, have acquired a negative reader's experience and may in future abandon reading in favour of other means of information and leisure activities.

It is therefore reasonable to talk of an unsustainable approach to reading acquisition in Latvia, which is promoted by the vague position of education policy makers and executive specialists in Latvia regarding the pre-school teachers' responsibility in reading acquisition process. This uncertainty permits each teacher to work according to his subjective preferences, fails to ensure content successiveness in reading acquisition between preschool and $1^{\text {st }}$ form and prevents children from acquiring an interested reader's experience. Shortcomings in pre-school education, especially compulsory preparation programmes of 5- to 6-year-olds for school, are identified in an auditing report from 7 May 2008 "Pirmsskolas izglītības īstenošanas atbilstība normatīvo aktu prasībām [Implementation of Pre-school Education in Accordance with Requirements of Normative Acts]" prepared by State Control of the Republic of Latvia. In order to improve the present situation, substantial changes ought to be introduced in the pre-school education system. It should be reoriented towards a sustainable development, thus fostering an environment favourable for child development, inter alia for the acquisition of a positive reading acquisition experience and grounded not only in teachers' subjective views but also in an objective, theoretically substantiated model (Krastiņa \& Salīte, 2009; Fulans, 1999; Ojala \& Talts, 2007).

Current initiatives include normative documents drawn by the Ministry of Education and Science and a project called "Obligātās pirmsskolas un sākumskolas izglītības izvērtējums un pilnveides iespējas [Evaluation of Compulsory Pre-school and Primary School Education and Possibilities for Its Improvement]" funded by Ministry of Education and Science and implemented at Daugavpils University. The aforesaid project is a significant conceptual step towards resolving, among other things, the issues of sustainable reading acquisition during 5- to 6-year-olds' compulsory preparation for acquisition of basic education. One of project results is a document entitled "Pamatprasmes bērnam, uzsākot pamatizglītības apguvi [Child's Basic Skills upon Commencing the Acquisition of Basic Education]" (Obligātās pirmsskolas un sākumskolas izglītības izvērtējums un pilnveides iespējas, 2009), which envisages that a child ought to be taught to read in pre-school. In other words, it determines pre-school teachers' responsibility for reading acquisition. Since the delineated basic skills are grounded in social constructivism, reading acquisition is also posited as acquisition of personally meaningful experience in a natural everyday situation (Obligātās pirmsskolas un sākumskolas izglīīibas izvērtējums un pilnveides iespējas, 2009). Therefore, the aforementioned basic skills are significant for reorienting the reading acquisition process towards sustainable development i.e. for shaping child's long-term interest in reading.

Study of teachers' experience in teaching reading during the preparation of 5- to 6-yearolds for acquisition of basic education

Applied research was conducted in October 2008 and November 2009, and, during this study, the activities that teachers proposed for development of reading literacy of 5- to 6year-olds during pedagogical process in pre-school were analysed. 


\section{Description of respondents}

25 teachers from all regions of Latvia (Latgale, Zemgale, Vidzeme, Kurzeme and Riga) were involved in the research. They are all part-time students who are taking the study programme "Pre-school Teacher" in Daugavpils University at the Faculty of Education and Management. All respondents are in-service teachers, experienced in working with children from compulsory preparatory groups. The sample was created according to the following criteria: (1) place of residence; (2) age; (3) work experience in pre-school (Table 1).

Table 1. Respondents' place of residence, age and work experience

\begin{tabular}{|c|c|c|c|}
\hline \multirow{5}{*}{ Place of residence } & Kurzeme & 5 & \multirow{5}{*}{25} \\
\hline & Vidzeme & 5 & \\
\hline & Latgale & 5 & \\
\hline & Zemgale & 5 & \\
\hline & Riga & 5 & \\
\hline \multirow{4}{*}{ Age } & under 28 years & 6 & \multirow{4}{*}{25} \\
\hline & 29-36 years & 8 & \\
\hline & $37-47$ years & 9 & \\
\hline & $48-61$ years & 2 & \\
\hline \multirow{3}{*}{ Work experience } & under 5 years & 10 & \multirow{3}{*}{25} \\
\hline & $6-10$ years & 9 & \\
\hline & above 10 years & 6 & \\
\hline
\end{tabular}

The research sample comprises an equal number of research participants from all regions of Latvia, which allows it to be considered representative. Respondents of various ages participated in the research: under 28 years, 29-36 years, 37-47 years and 48-61 years. Respondents attended school during different historical periods and in different educational systems having thus obtained different personal experiences in reading acquisition. Respondents' age can therefore be considered a significant feature of the sample. The third criterion for creating the sample is work experience. Respondents' work experience varies: beginning teachers with work experience below 5 years, teachers whose work experience ranges from 6 to 10 years and teachers whose work experience exceeds 10 years. Since the sample is characterised by three major determinant features, it can be considered representative.

\section{Substantiation of the chosen research method}

Since reading acquisition is an understudied topic in pre-school education in Latvia (Pirmsskolas izglīīibas īstenošanas atbilstība normatīvo aktu prasībām, 2008), qualitative research was selected for investigation of teachers' practical activity because it permits to ground description of the present situation on qualitative data collection and analysis. Quantitative data analysis has secondary importance in the current study; it was used merely to supplement the qualitative results.

Since it was crucial to examine the subjective experience of every teacher, data collection was performed by using methodological essay - an open-form description of the activities that were used to promote reading acquisition during one week. Essay analysis permitted us to reveal the teachers' views on the opportunities for reading acquisition in pre-school education institutions. 


\section{Research procedure, data and analysis}

At the beginning of this study, respondents were individually asked to choose a particular week and write an essay describing all reading acquisition activities that they had organised for 5- to 6-year-olds during this period.

Then every teacher's essay was analysed qualitatively with an aim to study (1) at which stage of pedagogical process teachers choose to develop children's reading literacy, (2) what are teachers' priorities in teaching reading - learning letters, reading syllables, reading words by syllables, reading entire words, reading entire sentences, reading text, (3) whether the activities that are suggested for reading acquisition are in line with the perspectives of sustainable development, which were defined in the materials of the project "Education for Change", implemented by a team from the Baltic Sea region (Jutvika, 2008): child-centred approach, process-oriented approach, integrated approach, community-oriented approach and pre-school education institution as learning environment. In order to identify the dominant tendencies in the process of reading acquisition, quantitative indicators were also applied - the number of activities used for the development of particular skills was determined.

Research data reveal that during one week, teachers used 274 activities for the development of reading literacy, which signifies that teaching reading is considered an important objective when working with 5- to 6-year-olds. Moreover, teachers identify opportunities for promoting reading acquisition throughout the entire pedagogical process. Reading acquisition activities are chiefly used during play lessons, but although in some cases teachers describe using reading acquisition activities in the morning and in the afternoon, and during walks, their number is limited - only 34 out of 274 activities. Thus it becomes clear that formal teaching dominates and opportunities to learn in a non-formal, natural environment are used but rarely. Therefore it is possible to ascertain that varied environment as an effective condition for sustainable learning is only partially used in preschool education.

Table 2 contains data from teachers' essays and commentary about development of 5- to 6-year-olds' reading literacy during pedagogical process in pre-school.

Table 2 . Reading skills to be acquired by 5 - to 6 -year-old children

\begin{tabular}{ll}
$\begin{array}{l}\text { Reading skills to be acquired } \\
\text { (number) }\end{array}$ & \multicolumn{1}{c}{ Commentary } \\
\hline Learning letters (112) & $\begin{array}{l}\text { Activities are varied, suitable for children with various types of } \\
\text { perception, related to development of phonematic hearing. }\end{array}$ \\
\hline Reading syllables (30) & $\begin{array}{l}\text { Albeit integrated in a play situation, it is mainly mechanic } \\
\text { reading for mastering reading technique. }\end{array}$ \\
\hline $\begin{array}{l}\text { Reading words by syllables } \\
(24)\end{array}$ & $\begin{array}{l}\text { Mastering reading technique dominates; although words to be } \\
\text { read are almost exclusively related to the topic of the week, their } \\
\text { content is of secondary importance. }\end{array}$ \\
\hline Reading entire words (65) & $\begin{array}{l}\text { The content of the word to be read is crucial; activities are } \\
\text { designed so that children simultaneously learn to decode the } \\
\text { word, perceive and comprehend its meaning. }\end{array}$ \\
\hline
\end{tabular}


Sequel to Table 2.

Reading entire sentences (32)

Reading for comprehension dominates, for instance, reading in order to understand task requirements. Reading technique is of secondary importance.

Reading text (11) Chiefly as a morning report, congratulation or surprise prepared by teacher.

An analysis of the essays allows us to conclude that activities for learning letters related to development of phonematic hearing are among the most frequently used. These activities are varied; they reveal the teacher's creativity and demonstrate that learning letters in a preschool pedagogical process is addressed with particular care. Such a teacher's choice corresponds to the basic reading skills (,Pamatprasmes pirmsskolēnam, uzsākot pamatizglīitibas apguvi”, 2005), but rouses suspicion whether such work with letters is adequately topical, interesting and personally meaningful for 5- to 6-year-olds. The world that surrounds the child is full of reading material that needs to be read in order to learn, find something out, understand, discover and use it. The letters, however, do not provide information. One can play with them, yet at this particular age children want to grow up sooner, inter alia read (Светловская \& Пиче-Оол, 2007; Chan, Juana, \& Foon, 2008). Essays confirm that teachers do not provide children with such an opportunity, because they focus on 'the connection between sound and letter'. Such learning can be considered mere rote repetition which can result in the child losing the motivation in learning how to read (Kemba Namdi, 2005). Consequently, this approach to reading acquisition is not childcentred, i.e. it is not based on child's interests and needs. It is not process-, but resultoriented (focused on leaning letters) (Jutvika, 2008). Learning letters cannot be regarded an integrated and community-oriented process in a natural environment, because it is aimed at individual acquisition of a specific and single skill via specially organised learning activities. It means that focus on learning letters does not purport a sustainable reading acquisition process in pre-school.

Research data confirm that with 5- to 6-year-olds, teachers also use activities that envisage reading syllables or reading words by syllables. Several pedagogues maintain that at the moment when the child has learned to blend letters into syllables (Ptičkina, 1997; Ptičkina, 1999; Anspoka, 2008; Hay \& Fielding-Barnsley, 2007; Landry, Swank, Smith, Assel, \& Gunnewig, 2006), he or she has learned to read. Consequently, it is possible to suggest that in this case teachers assume responsibility for children's reading acquisition. The proposed activities, however, are aimed at developing reading technique, not information gathering, because a syllable is not a meaningful language unit - it is a form that carries no meaning in itself. The short words that the child is encouraged to read are not always personally meaningful and interesting, whereas mere reading in order to master the technique and acquire the skill that adults deem so important might not be considered worthwhile by a preschooler. If the meaning of the word is detached from its form, the child loses the opportunity to think intensively (Выготский, 1997). Such activities cannot be regarded child-centred or process-oriented, or integrated. Neither are they communityoriented nor focused on natural learning, but are grounded in individual, mechanical drilling. Therefore, focus on reading syllables cannot ensure children's long-term interest in reading, which means that it is not oriented towards sustainable development.

Teacher's essays reveal that to promote reading acquisition in pre-school, children are involved in activities that envisage reading words. Such activities have more content value, because they require a comprehension of the read material. Yet they do not provide texts for reading, i.e. do not help children experience reading as an interesting process that uncovers different events related to the child's everyday life, as well as reveal a captivating 
fantasy world full of miraculous things (Kemba Namdi, 2005; Beauchat, Blamey, \& Walpole, 2009). Consequently, in this case activities are focused on mastering reading technique, because a word, just as a syllable, is not a meaningful language unit and does not convey a complete idea i.e. does not give information. Therefore, word reading activities are little related to the perspectives of sustainable development.

Table 2 reveals that sometimes more extensive units (sentences and text) are suggested for reading in pre-school pedagogical process. In this case, teachers have thought of reading as a whole (Kemba Namdi, 2005; Reyhner, 2008), i.e. have integrated its technical and content aspects, which is a significant feature of sustainable education (Jutvika, 2008). The content of activities that are grounded in reading sentences and texts is broader than required by the document "Preschooler's Basic Skills upon Commencing Acquisition of Basic Education" (Pamatprasmes pirmsskolēnam, uzsākot pamatizglītības apguvi, 2005). Such content corresponds to the skills that were highlighted in a study conducted at Daugavpils University (Obligātās pirmsskolas un sākumskolas izglītības izvērtējums un pilnveides iespējas, 2009) - the child reads and comprehends what has been read according to his or her abilities. Such activities are child-centred and process-oriented because they take into account the child's individual abilities and the learning process is meaningful. Consequently, suggesting more extensive language units for reading (sentence and text) introduces the perspectives of sustainability into reading acquisition process (Jutvika, 2008).

An analysis of the results allows us to conclude that teachers work by taking into consideration the basic skills that are outlined in the methodical material "I Want to Go to School" (Kañepēja, 2003a) and "Preschooler's Basic Skills upon Commencing the Acquisition of Basic Education" (Pamatprasmes pirmsskolēnam, uzsākot pamatizglītības apguvi, 2005) - fulfil the order of the state in the sphere of teaching reading. At the same time, reading acquisition process as described by respondents cannot generally be regarded as one promoting sustainable development, because teachers chiefly propose activities that are oriented towards mastering reading technique, i.e. a mechanical reading acquisition process that is not grounded in child-centred, integrated, process-oriented, communityoriented approaches and where learning environment is not considered as a condition for learning.

Because qualitative pedagogical activity begins with a clear formulation of aim and objectives (Anspoka, 2009; Fulans, 1999), it is possible to predict that as long as normative documents fail to outline uniform, theoretically substantiated reading skills to be acquired in pre-school, which are grounded in children's development peculiarities, interests and needs, neither successiveness between pre-school and primary school, nor sustainability will be ensured. On the grounds of a model proposed by Sterling (2004), which is based on four pillars (paradigm, aim, policy and practice), educational content and requirements for its acquisition that are determined on the state level (policy) and teachers' practical activity can only be considered as a part of the model that is most visible to the public. Reorienting the process of reading acquisition in pre-school towards sustainable development requires essential changes in the system of education, adopting holistic, systemic and critically-subjective paradigm. Thus, for long-term promotion of children's interest in reading to take place (Kemba Namdi, 2005; Roberts, Jurgens, \& Burchinal, 2005), the reading acquisition process ought to be grounded in the paradigm of sustainable education, i.e. in holistic, systemic and critically subjective approaches (Krastina \& Salīte, 2009).

Changing the paradigm and aim of education requires more extensive research. That is why this article proceeds only with reviewing methods for promoting reading 
acquisition and evaluating their correspondence to the perspectives of sustainable development (Jutvika, 2008).

\section{Theoretical review of methods for promoting reading acquisition which are popular in Latvia}

Theoretical substantiation of methods for promoting reading acquisition in Latvia is not extensive and is generally targeted at primary school teachers (Anspoka, 2008; Ptičkina 1999). Therefore a critical evaluation of these methods is required to determine the most appropriate method for working with preschoolers.

During the previous decades, two methods for promoting reading acquisition have been extensively used in Latvia and abroad: phonics method and whole language method (Karule, 1997; Ptičkina, 2003; Ptičkina, 1999; Lieǵeniece \& Nazarova, 1999; Reyhner, 2008).

Phonics method is based on the conclusion that reading is grounded in working with sounds (Элконин, 1974; Landry, Swank, Smith, Assel, \& Gunnewig, 2006). This method helps to develop phonematic hearing which is significant for successful acquisition of Latvian spelling and can therefore be considered the strong point of phonics method. It allows us to conclude that the use of this method in the Latvian language is expedient.

By means of phonics method, children initially learn to hear different sounds, then master the letters that correspond to sounds and attempt to read the letters into syllables, words, phrases, sentences. (Элконин, 1974; Ptičkina, 1997; Ptičkina, 1999; Anspoka, 2008; Landry, Swank, Smith, Assel, \& Gunnewig, 2006; Bowey, 2006). Therefore, a child who is just beginning to experience the joy of reading reads words or even syllables that contain the letters that have been learned, but these words or syllables often are not interesting and carry no personal meaning to the child. "A word that has no meaning is not a word but mere empty sound" (Vigotskis, 2002). Thus the most pronounced drawback of this method is exceedingly great attention to mastering the technique of reading and little regard for children's interests and needs (Выготский, 1997; Anspoka, 2008; Milosovic, 2007; Jalongo, 1998). Phonics method lays particular emphasis on teacher-centred educational process and mastering the technique of reading as the intended result; cooperation and natural environment play no decisive role. Thus, this method is little related to the perspectives of sustainable development and is not oriented towards acquisition of an interested learner's experience.

Another significant shortcoming of phonics method is the fact that a purposeful acquisition of letters in pre-school is only begun in preparatory groups of 5- to 6-year-olds (Ptičkina, 2003), although children display interest in letters much earlier and by the age of 5 many have already learnt all letters owing to reading-favourable environment and even have begun reading (Anspoka, 2009; Доман \& Доман, 2008; Justice, Skibbe, Canning, \& Lankford, 2005; Hannon \& James, 1990).

An alternative for phonics method in Latvia is whole language method. Its methodological basis is holistic approach (Liegeniece \& Nazarova, 1999; Gutknecht, 1991; Goodman, 1986; Stahl \& Kuhn, 1995) that envisages shifting the dominance from teacher as the source of information towards teacher as facilitator and organiser of child's learning. It also emphasises child's motivation to demonstrate own initiative to involve in reading and writing processes. Crucially, the child should desire to read, and reading should become a meaningful activity and child's own free choice. That is why the most significant 
aspect of whole language method is the creation of reading-favourable environment (Liegeniece \& Nazarova 1999; Goodman, 1986; Hempenstall, 1997).

Whole language method is grounded in child's interest, but interest in reading material (letters, words, text and book) appears early (Доман \& Доман, 2008; Hannon \& James, 1990). Therefore, this method envisages that the environment which is favourable for reading acquisition excites a very early interest in reading and its long-term development is enhanced by reading personally meaningful and useful text. It can thus be concluded that whole language method is oriented towards sustainable development. In Latvia the use of whole language method in working with 5- to 7-year-olds has been methodologically substantiated (Lieǵeniece \& Nazarova, 1999); "Ābecīte pirms skolas [ABC before School]" has been prepared for practical application (Ptičkina, 2003). Yet whole language method is not referred to in the Educational Programme for Pre-school (Pirmsskolas izglītības programma pirmsskolas izglītības iestādēm, 1998) or in the document "Preschooler's Basic Skills upon Commencing Acquisition of Basic Education" (Pamatprasmes pirmsskolēnam, uzsākot pamatizglīin̄bas apguvi, 2005). The study that has been outlined in the previous section of this article likewise confirms that in pre-school pedagogical process work is chiefly organised around phonics method. It means that in their everyday work teachers follow recommendations from executive specialists in the field. In order to achieve changes in the sphere of reading acquisition requires much closer cooperation between practicing teachers and academicians when designing normative documents, methodical materials and teaching aids (Anspoka, 2009).

Since the issue of reading acquisition (when to start teaching the child how to read and how to organise the teaching) is becoming more and more topical in Latvia, foreign experience is also gaining popularity - Doman (Доман \& Доман, 2008) reading system and ALI active reading acquisition programme.

Doman \& Doman (Доман \& Доман, 2008) are grounding their arguments in results of medical research. They argue that the most favourable time for development of reading literacy is the period from birth till five years of age. "It is the time in a child's life when his or her brain is open to any information. The child acquires information without conscious effort. It is a period when he or she can easily and naturally learn how to read. During this particular time the child ought to be provided with opportunities to acquire all basic information about reading and writing in order to avoid spending much time and effort on it at the age of six to ten" (Доман \& Доман, 2008, pp. 37-38).

Doman \& Doman believe that the chief success factors for early reading acquisition are good spirits, respect towards the child, sufficient amount of reading material that is interesting and significant for the child and brief but dynamic and regular lessons. Reading material ought to be prepared by taking into consideration the child's age and individual needs. Working with this material according to the system permits children quickly to learn to read because adults offer a reading game that is interesting and captivating. On no account should the child be forced to learn or his performance tested in order to find out what he or she does not know (Доман \& Доман, 2008). Thus it is possible to identify similarities between the method by Doman \& Doman, whole language method and the perspectives of sustainability listed by Jutvika (2008). This leads to the conclusion that the child masters reading as an interesting and personally significant pursuit.

Active Reading (ALI) programme (Aktīvās lasīšanas iespēju programmas (ALI programmas), 2007) is suggested to teachers as another alternative for promoting preschoolers' reading acquisition. It is grounded in a belief that reading acquisition cannot be begun before the age of 6 . Consequently, the period from 0 till 5 years is meant for preparation for reading acquisition process, i.e. the development of child's cognitive, 
linguistic and socially-emotional abilities. The ALI programme is grounded in an adult's emotional daily interaction with the child, in creating the environment that meets the child's needs, abilities and interests (child-centred approach, learning environment), in integration of play lessons into daily regime (integrated approach, process-oriented approach), in recognition of child's achievements, in constant and qualitative dialogue between adult and child (community-oriented approach). Thus, the ALI programme corresponds to the perspectives of sustainability, although it cannot be used as a basic method for promoting preschoolers' reading acquisition. The ALI programme is grounded in outdated psychological considerations that children can only be offered such learning activities which they can perform independently at their presently achieved development level (Vigotskis, 2002). It means that the ALI programme does not advance children's development, but uses the existing skills and abilities, already achieved by children in their biological and psychological development.

\section{Evaluation of reading acquisition methods in the context of sustainable development}

The summary of the results of this study allows us to conclude that in Latvia one can observe a discrepancy between the most recent local and foreign pedagogical tendencies that are grounded in the perspectives of sustainability and between the approach outlined in the documents that regulate pre-school teachers' work and the behaviouristic approach to teaching that is still used in pedagogical process. In such a context, it is impossible to identify reading acquisition as a priority in education. At the same time, research within the Programme for International Student Assessment conducted by Organisation for Economic Cooperation and Development includes high reading literacy and interest in reading among the chief success factors. Finnish experience in promoting reading acquisition (Krasovska, 2009) confirms the need for significant changes in Latvia that would be directed towards sustainability-oriented reading literacy development. It means that children already in preschool ought to learn reading as a meaningful, interesting, personally significant and practically useful skill. In other words, reading acquisition ought to be reoriented towards sustainable development, thus creating a new approach to reading acquisition that would integrate the strong points of already existing reading acquisition methods (Table 3 ).

Table 3. Strong points of different reading acquisition methods

\begin{tabular}{cllll}
\hline & Phonics method & $\begin{array}{l}\text { Whole } \\
\text { language } \\
\text { method }\end{array}$ & Doman method & ALI programme \\
\hline \multirow{2}{*}{ ptrong } & $\begin{array}{l}\text { Development of } \\
\text { phonematic } \\
\text { hearing }\end{array}$ & $\begin{array}{l}\text { Reading } \\
\text { acquisition is } \\
\text { child-centred, } \\
\text { meaningful and } \\
\text { personally } \\
\text { significant }\end{array}$ & $\begin{array}{l}\text { Child-centred } \\
\text { activities for speech } \\
\text { reading } \\
\text { acoundisition } \\
\text { child's innate } \\
\text { cognitive abilities }\end{array}$ & $\begin{array}{l}\text { development and } \\
\text { development of } \\
\text { phonematic hearing } \\
\text { in cooperation with } \\
\text { andult in an } \\
\text { emotionally } \\
\text { favourable } \\
\text { environment }\end{array}$ \\
\hline
\end{tabular}


When creating a sustainability-oriented approach for reading acquisition in the Latvian context, it is essential to retain the development of phonematic hearing (Ptičkina, 1997; Ptičkina, 1999; Anspoka, 2008), because it guarantees grammatically correct reading and writing in future. This approach ought to be child-centred i.e. it should meet child's interests, needs and abilities (Lieǵeniece \& Nazarova, 1999; Goodman, 1986; Stahl \& Kuhn, 1995). Selection of the reading material is crucially important because, when offered personally meaningful and interesting information in emotionally favourable everyday environment and in cooperation with an adult, the child learns driven by own initiative and finds joy in the process (Lieǵeniece \& Nazarova, 1999; Ptičkina, 2003; Доман \& Доман, 2008; Aktīvās lasī̌sanas iespēju programmas (ALI programmas), 2007; Goodman, 1986; Hannon \& James, 1990). Since the strong points of the aforementioned methods are suggested for application in a sustainability-oriented approach to reading acquisition, they can be called sustainability aspects of reading acquisition methods. Therefore, it is possible to propose some suggestions for organising a sustainable reading acquisition process in preschool.

\section{Suggestions for organising a sustainable reading acquisition process in pre-school}

1. It is essential to proceed from the child's desire to learn and from his or her personal interest and avoid teacher-dominated instruction. The teacher's major task is to provide children with captivating reading material, demonstrate that reading can help obtain useful information and emotional satisfaction and use reading as much as possible during the day, i.e. it is important to create a readingfavourable environment in the group.

2. It is essential to trust children and wait until they display a desire to read, discern the child's interest, support and encourage it and on no account hasten or force him or her to read, but stimulate the desire to read and comprehend written text.

3. It is crucial to be there for the child and help him or her when the child displays a willingness to read; allow each child to choose reading material that corresponds to his or her wishes and needs - alone or in the company of peers or adults. After some preparatory training, parents can also be involved in reading acquisition process.

4. It is important to support the child even when he or she has learned to read and celebrate his or her success. One should not demand that the child reads when the teacher wishes him or her to do so; it is more important to develop a readingfavourable environment.

These suggestions can be used in working with children of various ages - readingfavourable environment can be created for 1.5-year-old children or five-year-olds, each child can learn in his or her own pace, reading literacy is acquired as a meaningful process. Also, children ought to be involved in activities for mastering reading technique, but they should be organised as merry plays.

The aforesaid suggestions (1) incorporate the strong points of reading acquisition methods discussed above; (2) propose ensuring sustainability-oriented reading acquisition process by creating a reading-favourable environment; (3) are directed towards fostering reading literacy in pre-school and its long-term development; (4) constitute an attempt to think of raising a generation of interested and responsible readers; (5) are open for creative complementation from the part of every teacher; (6) match international experience in the area of reading acquisition. 


\section{Conclusions}

Information that has been obtained during the present study reveals Latvian experience in the area of reading acquisition and allows us to conclude that there is an evident lack of successiveness between reading acquisition in pre-school and basic education. Lack of clear state regulations and requirements regarding 5- to 6-year-olds' reading acquisition in education programmes for compulsory preparation for school results in a situation when the practice of pre-school teachers differs considerably: some teach reading, others only introduce letters. Reading acquisition process in pre-school is generally organised around phonics method which is incorporated in the aforementioned recommendation documents, but is grounded in mechanical drilling and does not excite interest in reading. On the other hand, whole language method, which has a sound sustainability-oriented theoretical substantiation, is not included in the support materials that are specially prepared for preschool teachers. Moreover, in Latvia reading acquisition is only discussed in the context of compulsory preparation of 5- to 6-year-olds for school. At the same time numerous studies confirm that children display interest in reading as a means of cognising the world ever since their birth. If the child is given an opportunity to act in a reading- favourable environment, reading acquisition proceeds smoothly and with joy. The suggestions that were presented in the previous section could promote sustainable development oriented reading acquisition among preschoolers.

\section{References:}

Aktīvās lasīšanas iespēju programmas (ALI programmas) interaktīvas lasīšanas darbības [Interactive reading activities in a programme of possibilities of active reading (PAR)]. (2007). Riga: Ministry of Children and Family Affairs.

Anspoka, Z. (2008). Latviešu valodas didaktika 1. - 4. kl. [Latvian language didactics for form 1-4]. Rīga: RaKa.

Anspoka, Z. (2009). Pirmsskolas un skolas izglītības pēctecība: problēmas un risinājumi [Successiveness between pre-school and school education: Problems and solutions]. Skolotājs [Teacher], 4(76), 10-18.

Beauchat, K. A., Blamey, K. L., \& Walpole, S. (2009). Building preschool children's language and literacy one storybook at a time. The Reading Teacher, 63(1), 26-39.

Bowey, J. A. (2006). Need for systematic synthetic phonics teaching within the early reading curriculum. Australian Psychologist, 41(2), 79-84.

Chak, A. (2007). Teachers' and parents' conceptions of children's curiosity and exploration. International Journal of Early Years Education, 15(2), 141-159.

Chan, L., Juan, C. Z., \& Foon, C. L. (2008). Chinese preschool children's literacy development: from emergent to conventional writing. Early Years. 28(2), 135148.

Fulans, M. (1999). Pārmaiņu spēki [Powers of change]. Rīga: Zvaigzne ABC.

Geske, A., \& Grīnfelds, A. (2006). Izglītības pētniecība [Educational research]. Rīga: LU Akadēmiskais apgāds.

Geske, A., \& Grīnfelds, A. (2001). Izglītības pētījumu metodologija un metodes [Methodology and methods of educational research]. Rīga: RaKa.

Geske, A., \& Ozola, A. (2007). Skolēnu sasniegumi lasītprasmē Latvijā un pasaulē [Pupils' achievements in reading literacy in Latvia and globally]. Rīga: LU Akadēmiskais apgāds.

Goodman, K. S. (1986). What's whole in whole language? Portsmouth, NH: Heinemann. 
Gutknecht, B. (1991). Transition in reading instruction: From a skills acquisition to a whole language model. Journal of Instructional Psychology, 18. Retrieved October 10, 2008, from EBSCOhost.

Hannon, P., \& James, S. (1990). Parents' and teachers' perspectives on pre-school literacy development. British Educational Research Journal, 16. Retrieved October 17, 2009, from EBSCOhost.

Hempenstall, K. (1997). The whole language - phonics controversy: An historical perspective. Educational Psychology, 17. Retrieved October 17, 2009, from EBSCOhost.

Horner, H. L. (2004). Observational learning during shared book reading: The effects on preschoolers attention to print and letter knowledge. Reading Psychology, 25, $167-188$.

Hay, I., \& Fielding-Barnsley, R. (2007). Facilitating children's emergent literacy using shared reading: A comparison of two models. Australian Journal of Language and Literacy, 30(3), 191-202.

Izglītības likums (1998, ar grozījumiem 05.07.2001.) [Law on Education (1998, Amendment of July 5, 2001]. Retrieved October 10, 2008, from Ministry of Education and Science website: http://www.likumi.lv/doc.php?id=50759

Jalongo, R. M. (1998). On behalf of children: "The fuss over phonics". Early Childhood Education Journal, 26(1), 1-6.

Justice, L. M., Kaderavek, J. N., Fan, X., Sofka, A., \& Hunt, A. (2009). Accelerating preschoolers' early literacy development through classroom-based teacher-child storybook reading and explicit print referencing. Language, Speech, and Hearing Services in Schools, 40, 67-85.

Justice, L. M., Skibbe, L., Canning, A., \& Lankford, C. (2005). Pre-schoolers, print and storybooks: An observational study using eye movement analysis. Journal of Research in Reading, 28(3), 229-243

Jutvika, G. (2008). Izglītība pārmaiņām: ilgtspējīgas attīstības mācī̌̌anas un mācīšanās rokasgrāmata [Education for change: Handbook of teaching and learning for sustainable development]. Rīga: Gandrs.

Kaņepēja, R. (Ed.). (2003a). Es gribu iet skolā [I want to go to school]. Rīga: Puse Plus.

Kaņepēja, R. (2003b). Iepazīstināšana ar apkārtni. Literatūra. Runas attīstīšana. Rakstīt un lasītmācīšana [Getting to know the surroundings. Literature. Speech development. Teaching reading and writing]. In R. Kaņepēja (Ed.), Es gribu iet skolā [I want to go to school] (pp. 51-67). Rīga: Puse Plus.

Karule, A. (1997). Ábeces mācǐšanas metodika [Methods of teaching ABC]. Rīga: Zvaigzne ABC.

Kemba Namdi, A., (2005). Guide to teaching reading at the primary school level [Electronic version]. France: Paris.

Krasovska, M. (2009). Lasǐšanas veicināšana Somijā [Promoting reading acquisition in Finland]. Retrieved December 21, 2009, from: http://www.lnb.lv/lv/ bibliotekariem/Izdevumi/pielikumi/biblioteku-pasaule/BP-47-Marlena-Krasovska

Krastiņa, E., \& Salīte, I. (2009). Par pirmsskolas izglītības programmas modeli. Obligātās pirmsskolas un sākumskolas izglītības izvērtējums un pilnveides iespējas [On preschool education programme model: Evaluation of compulsory pre-school and primary school education and possibilities for its improvement] (pp. 169-172). Retrieved September, 17, 2009, from Ministry of Education and Science website http://izm.izm.gov.lv/upload_file/Petijums_Daugavpils_Universitate.pdf 
Landry, S. H., Swank, P. R., Smith, K. R., Assel, M. A., \& Gunnewig, S. B. (2006). Enhancing early literacy skills for preschool children: Bringing a professional development model to scale. Journal of Learning Disabilities, 39(4), 306-324.

Lieǵeniece, D., \& Nazarova, I. (1999). Veseluma pieeja valodas apguvē [Whole language approach in language acquisition]. Rīga: RaKa.

Milosovic, S. (2007). Building a case against scripted reading programs. Education Digest, $73(1), 27-30$.

Molfese, V. J. (2006). Introduction to the special series: Early reading skills. Journal of Learning Disabilities, 39(4), 295-295.

Nurmilaakso, M. (2009). Preschool and primary school children as learners in 2030: Views of Finnish student teachers. Journal of Teacher Education for Sustainability, 11(1), 75-85.

Obligātās pirmsskolas un sākumskolas izglītības izvērtējums un pilnveides iespējas [Designing evaluation of compulsory pre-school and primary school education and possibilities for its improvement]. (2009). Retrieved September, 17, 2009, from Ministry of Education and Science website http://izm.izm.gov.lv/upload_file/ Petijums_Daugavpils_Universitate.pdf.

Ojala, M., \& Talts L. (2007). Preschool achievement in Finland and Estonia: Cross-cultural comparison between the cities of Helsinki and Tallinn. Scandinavian Journal of Educational Research, 51(2), 205-221.

Pamatprasmes pirmsskolēnam, uzsākot pamatizglītības apguvi [Preschooler's basic skills upon commencing acquisition of basic education]. (2005). Retrieved November 19, 2009, from Ministry of Education and Science website http://izm.izm.gov.lv/nozares-politika/izglitiba/vispareja-izglitiba/pirmsskolasizgl.html

Pirmsskolas izglītības ìstenošanas atbilstība pamatizglītības satura apguvei [Correspondence of pre-school education implementation to the acquisition of basic education content]. (2008). Auditing report by State Control of the Republic of Latvia. Retrieved September 17, 2009, from http://www.lrvk.gov. lv/printpage.php?\&id=1759\&start=40\&data=/index.php? cancbutt $=$ Nodz $\%$

Pirmsskolas izglītības programma pirmsskolas izglītības iestādēm [Pre-school education programme for pre-school education institutions]. (1998). Rīga: SIA "Mācību Apgāds NT".

Prets, D. (2000). Pedagoga rokasgrāmata [Teacher's handbook]. Rīga: Zvaigzne ABC.

Ptičkina, Ā. (1997). Kā mācīsim bērnus lasìt un rakstīt [How to teach children to read and write]. Rīga: Zvaigzne ABC.

Ptičkina, Ā. (1999). Lasī̌šanas mācības sākumskolā [Reading acquisition in primary school]. Rīga: Pētergailis.

Ptičkina, Ā. (2003). Zīlīte. Ābecìte pirmsskolai: padomi vecākiem un pedagogiem [Little tit. ABC for pre-school: Guide for parents and teachers]. Rīga: Zvaigzne ABC.

Puškerevs, I. (2001). Attīstības psihologija [Development psychology]. Rīga: RaKa.

Reyhner, J. (2008). Phonics versus whole language. Retrieved September 17, 2009, from http: //jan.ucc.nau.edu/ jar/Reading_Wars.html

Roberts, J., Jurgens, J., \& Burchinal, M. (2005). The role of home literacy practices in preschool children's language and emergent literacy skills. Journal of Speech, Language, and Hearing Research, 48, 345-359.

Stahl, S., \& Kuhn, M. (1995). Does whole language or instruction matched to learning styles help children learn to read? School Psychology Review, 24(3). Retrieved December 9, 2007, from EBSCOhost. 
Stephen, C. (2003). What makes all-day provision satisfactory for three and four year olds? Early Child Development and Care, 173(6), 577-588.

Sterling, S. (2004). Higher education, sustainability, and the role of systematic learning. In P. B. Corcon, \& A. E. J. Wals (Eds.), Higher education and the challenge of sustainability. Problems, promises, and practice (pp. 64-78). Dordrecht: Kluwer Academic Publishers.

Svence, G. (1999). Attīstības psihologija [Development psychology]. Rīga: Zvaigzne ABC.

Vigotskis, L., (2002). Domāšana un runa [Thinking and speech]. Madona: Madonas poligrāfists.

Watkins, Ruth, V., Bunce, \& Betty, H. (1996). Natural literacy: Theory and practice for preschool intervention programs. Early Childhood Special Education, 16(2), 191220.

Выготский, Л. С. (1997). Вопросы детской психологии [Issues of child psychology]. CПб.: Союз.

Доман, Г., \& Доман, Д. (2008). Как научить своего малыша читать [How to teach your baby to read]. Рига: Juridiskais birojs Vindex, SIA.

Светловская, Н. Н., \& Пиче-Оол, Т. С. (2007). Как помочь детям, которые не хотят учиться читать [How to help children who don't want to read]. Москва: Аркти.

Элконин, Д. Б. (1974). Психология обучение младшего школьника [Psychology of teaching junior pupils]. Москва: Знание.

\section{Acknowledgement:}

This study was supported by ESF project "Support to Implementation of Doctoral Studies at Daugavpils University", agreement No. 2009/0140/1DP/1.1.2.1.2/09/IPA/VAA/015, individual agreement No. 14-21/33-2009/44.

\section{Correspondence:}

Sandra Zariņa, Mg. paed., PhD student, Daugavpils University, Parādes Street 1, Daugavpils, LV-5401. Email: sandrina.zarina@inbox.lv 